\title{
La imagen fotográfica en la obra de Gerhard Richter
}

\author{
The photographic image in Gerhard Richter's work
}

Óscar Ortega Ruiz

Universidad de Málaga, España (oscaror9@msn.com)

Recibido el 25 de Noviembre de 2016, revisado el 3 de Diciembre de 2016; aceptado el 10 de Diciembre de 2016; publicado el 1 de Marzo de 2017.

RESUMEN: Gerhard Richter, como muchos contemporáneos, ha tomado la imagen fotográfica como punto de partida de su experimentación artística. El uso pictórico que ha hecho de la fotografía o, si se quiere, su concepción fotográfica de la pintura entran en conflicto con la omnipresente cultura de la imagen comercial de nuestras sociedades. Mientras su Atlas nos presenta el mundo bajo los signos de la banalidad y la transitoriedad, sus pinturas abstractas procuran acceder a cierta performatividad sin tema.

PALABRAS CLAVE: Imagen, Fotografía, Pintura, Atlas, Memoria.

\begin{abstract}
Gerhard Richter, like many other contemporaries, has taken the photographic image as a starting point for his artistic search. The pictorial use he has made of photography or, if you will, his photographic conception of painting come into conflict with the omnipresent culture of the commercial image of our societies. While its Atlas presents us the world under the signs of banality and transience, his abstract paintings seek access to certain performativity without issue.
\end{abstract}

KEYWORDS: Image, Photography, Painting, Atlas, Memory.

Gerhard Richter es unánimemente aclamado como uno de los grandes pintores contemporáneos. Ha expuesto por toda Europa y Estados Unidos. Entre los muchos reconocimientos que ha obtenido, podemos mencionar el Premio Kokoschka, el de la Academia Estadounidense de Artes y Letras, el Arnold-Bode-Preis de documenta y el León de Oro de la Bienal de Venecia. Al igual que todo pintor de su generación, Richter se ha visto obligado a enfrentarse al dilema de cómo seguir pintando en un mundo tomado por la imagen fotográfica. Gran parte de su itinerario artístico puede entenderse a partir de la novedosa visión del medio fotográfico que ha sido capaz de integrar como parte de su propia obra. Una indagación de matriz e intelección estrictamente visual, que da pie a una interesante dinámica de transformaciones e inversiones en el seno de la relación entre pintura y fotografía.

\section{El Atlas y sus antecedentes}

En 1962 Gerhard Richter empieza a recopilar un gran número de fotografías, actividad que continuará desde entonces y que quedará asociada a su empresa artística. El material visual que 
selecciona para componer el Atlas, como denomina a las series de paneles que forma con el material recopilado, es muy heterogéneo: recortes de revistas, fotografías, collages, apuntes, dibujos, proyectos expositivos, ejercicios experimentales, etc. Todo puede encontrar cabida en el Atlas: el entorno familiar del artista, pruebas de colores, recortes pornográficos, paisajes, bodegones y un largo etcétera (casi ochocientos paneles a día de hoy). Documentos que, considerados individualmente, se nos aparecen mudos, sin trascendencia, pero que juntos parecen sugerir vinculaciones no inmediatamente evidentes. Sus características permiten considerar al Atlas como una obra autónoma y, como tal, se ha presentado en numerosas ocasiones.

Aunque podríamos aventurarnos a ensayar clasificaciones de este material conforme a criterios temáticos o formales, fácilmente se comprende que se trata de una obra potencialmente inacabable e irreductible a una definición que la enmarque (Giaveri, 2011, p. 127). Tenemos que confiarnos a la visión del artista, que se sirve de las imágenes del Atlas como de un espejo que refleja líneas narrativas por él propuestas, pese a las múltiples lecturas que ofrece. En busca de antecedentes de este modo de operar, podemos remitirnos al "Media Scrap Book" de Hannah Höch de 1933. Se trataba de un intento de organizar grandes cantidades de fotografías según criterios de archivo, una puesta a prueba de la competencia mnemónica del sujeto frente a la, por entonces emergente, cultura mediática.

Antes incluso de Höch, en 1925, el historiador del arte Aby Warburg había concebido el "Mnemosyne Atlas". En él recopiló imágenes de motivos recurrentes de expresión gestual y corporal del arte, a las que llamó "fórmulas del pathos" (Buchloh, 1999, 150). Para Warburg, la memoria social colectiva podría rastrearse a través de las diversas capas de transmisión cultural, entre las que el arte ocupa un lugar primordial: "El acto de interponer una distancia entre uno mismo y el mundo exterior puede calificarse de acto fundacional de la civilización humana; cuando este espacio interpuesto se convierte en sustrato de la creación artística, se cumplen las condiciones necesarias para que la conciencia de la distancia pueda devenir una función social duradera, [...] la suficiencia o el fracaso de la cual, como instrumento espiritual orientador, determina el destino de la cultura humana" (Warburg, 2010, 3). Su Atlas, por otra parte, pretendía también erigirse en contra de los métodos y categorías de descripción exclusivamente formal o estilística de la disciplina de la historia del arte.

Tanto el Atlas de Warburg como el de Richter abordan cuestiones semejantes relacionadas con las posibilidades de la experiencia mnemónica visual, pero bajo circunstancias históricas contrapuestas: el primero arranca en el inicio del proceso histórico que culminaría con el cataclismo más devastador de la historia humana, provocado por el fascismo germánico; el segundo contempla retrospectivamente dicho trauma desde el interior del espacio geopolítico de la sociedad que lo desencadenó. Ahora bien, las imágenes se nos ofrecen desde una objetividad desprovista de cualquier intención moralizante. Ya Adorno había considerado el antisubjetivismo como el elemento conformador primordial de la estética del collage y del fotomontaje, al incorporar una crítica a lo que después se denominaría "la función autor". Esta es una de las características conceptuales principales del Atlas: una construcción discursiva de la memoria evitando interpretaciones. 
Benjamin sugería en 1931 que el clímax histórico del medio fotográfico tuvo lugar hacia 1860. En esa época pensaba que se había completado la transición del objeto aurático del arte precedente que decaía entonces ante las nuevas formas de reproducción tecnológica. La fotografía aún podía contener, sin embargo, la promesa social de nuevas formas de interacción (Buchloh, 1999, pp.153-159). Apenas veinte años después, empezaba a ser posible imaginar que la cultura de masas amenazaría con provocar el declive de la experiencia mnemónica y del pensamiento histórico. Siegfried Kracauer consideraba que la presencia universal de la imagen fotográfica acabaría destruyendo los procesos cognitivos tal y como se habían venido concibiendo hasta entonces: "No debería ser así; sin embargo, las revistas norteamericanas, a las que las de otros países emulan frecuentemente, sin duda equiparan el mundo con la esencia de las fotografías" (Kracauer, 2008, p.33).

En este contexto intelectual hemos de situar el nacimiento del Atlas de Richter. El impulso inicial para crearlo fue desencadenado por la experiencia de pérdida de su contexto familiar y social, tras su huida a la Alemania del Oeste. Una Alemania de postguerra embarcada en un rechazo colectivo de la historia reciente, mientras era objeto de una invasión de producción fotográfica programada para fomentar el deseo y el consumo superfluo. Richter encara el problema de cómo concebir la pintura en confrontación con este abrumador aparato de la cultura fotográfica de masas. El Atlas es, al mismo tiempo, instrumento subalterno y objeto independiente, recorrido biográfico y ejercicio formal de contenidos, obra con sentido propio e indagación abierta que acompaña y complementa las experiencias pictóricas de Richter (Zweite, 1999, p. 232). En él, la memoria se concibe como una arqueología de aportes visuales, cada uno de ellos con su propio registro psíquico.

Mientras que los cuatro primeros paneles están constituidos por imágenes fotográficas de miembros de la familia, el quinto se compone de recortes de prensa y revistas. De esta forma, Richter contrapone la construcción de identidad pública por la cultura mediática a la construcción de identidad privada a través de la fotografía familiar. Tal y como expuso Kracauer, con el ascenso de la cultura mediática, el sujeto ya no se constituye conforme a los modelos de continuidad de la etnia, la familia y las costumbres del grupo social. En cambio, los nuevos signos y lenguajes traídos por los medios visuales de la cultura de masas vinculan el deseo de identidad en distintos registros de representación.

Mientras en el Atlas Richter nos presenta el mundo de las personas, de las cosas y de la naturaleza bajo el signo de la transitoriedad, en sus pinturas abstractas todo aparece abierto al futuro bajo el signo de la esperanza. El Atlas y la obra pintada muestran visiones complementarias: el primero está cerrado bajo aspectos de contenido, aunque estructuralmente puede ser ampliado y modificado continuamente, mientras que la obra pictórica se abre utópicamente a posibilidades futuras a la vez que se encuentra estructuralmente acabada y sin posibilidad de modificación. Para Armin Zweite, esta doble dialéctica convierte al Atlas en una obra fascinante, aunque su apariencia visual sea tan discreta y contenida (Zweite, 1999, 238). 


\section{Entre la pintura y la fotografía}

El uso pictórico que hace Richter de la fotografía o, más bien, su concepción fotográfica de la pintura se opone y contrasta con los modelos kitsch de la industria cultural. Se trata de una resistencia consciente frente a las tendencias que buscan asimilar actividad artística y tecnología estética. Desde este punto de vista, se ha hablado de cierto romanticismo en la obra de Richter, que mostraría cierta nostalgia por la pérdida de la comunidad orgánica y preindustrial, que habría quedado desarticulada en un proceso iniciado por el fascismo, continuado por el estalinismo y, posteriormente, por la industria cultural gestora de los medios de comunicación (Chevrier, 1999, pp. 177-179). En uno de los paneles del Atlas, Richter coloca un grupo de imágenes de presos de los campos de concentración junto a escenas de voyeurismo pornográfico, con su estetización sensacionalista. De este modo, el artista nos quiere transmitir la imposibilidad de que la cultura alemana pueda afrontar un duelo por el desastre fascista en medio del amnésico consumismo capitalista.

Richter, como Polke, ha sabido asimilar el Pop Art y, en base a su comprensión crítica del mismo, reorienta su obra enlazando con la tradición europea de la pintura, desde la que proyecta una mirada que relativiza la cultura mediática y sus pretensiones de apropiarse de todo. A la sombra de esta reflexión, nos muestra una pintura que no es ni un medio de apropiación de la realidad ni del conocimiento del mundo, sino un medio creador de analogías para aquello que es inefable o inconcebible. Nos ofrece imágenes de un "no comprensible" que podría ser negado al entendimiento humano (Zweite, 1999, p. 205). En su obra se advierte, además, una cierta obstinación por pintar que puede interpretarse como signo de rebeldía frente a la mediocridad de la cultura mediática.

Muestra de esta actitud son sus pseudofotografías, pintadas al óleo sobre tela. Se trata de una inversión de la relación entre pintura y fotografía, surgida de la constatación de que la imagen fotográfica es la referencia visual de nuestro tiempo. Reproducida por un pintor, una foto hecha originalmente sin intención artística, sufre una transformación que le dota de una significación y un valor de ejemplaridad. Esta falsa fotografía deja de ser principalmente huella indicial de la realidad y se nos muestra como signo revelador de la manera de ver de la estética de masas. Richter busca, con este proceder, traducir en imágenes existentes de la memoria privada o colectiva muestras del estado de la conciencia común. Para Rochlitz, el artista desea expresar, mediante la imagen, el "punto en que nos hallamos", no en función de un análisis sociológico, sino de una experiencia histórica (Rochlitz, 1999, p. 262).

\section{Lo indicial, lo mnemónico y lo banal}

La fotografía no es sólo una huella indicial ni una imagen reproductible, es también una fijación en la memoria. Esa capacidad de poderse registrar es lo que convierte a la fotografía en una mnemotecnia. Ya Delacroix, a mediados del XIX, defendía que la exactitud de la reproducción de la imagen debe ceder protagonismo frente a la precisión o justesse (Chevrier, 1999, 186). Así formuló una estética de la fotografía basada en la imperfección del proceso. De esta forma resaltaba el elemento de contraste, de contramodelo de la fotografía y, por otra, planteaba un desafío a la disciplina pictórica que debía enfrentarse y trascender esa mnemotecnia. 
La fotografía se encuentra, de este modo, en el centro de una serie de investigaciones y debates artísticos que, ya desde entonces, tratan de establecer una relación específicamente meditada con las imágenes, llamada a dirigir la sensibilidad de los contemporáneos hacia aspectos todavía inadvertidos. Así, Rosalind Krauss considera que el uso de técnicas indiciales asegura, de por sí, la actualidad de la obra en la época de la modernidad tardía. Rochlitz señala los ejemplos de Cindy Sherman y Jeff Wall como artistas que abordan la contingencia indicial en función de imágenes preconcebidas (Rochlitz, 1999, pp. 246-251). Tanto en Richter como en Wall, la obra fotográfica pasa por una referencia a la pintura, técnica en el caso de Richter, iconográfica en el caso de Wall.

Richter aborda estas cuestiones desde una actitud radicalmente antiestética y, la mayor parte de las veces, de la mano del concepto de banalidad. En una entrevista de 1985 declara Richter: "Utilizo lo que llaman banal para demostrar que lo banal es importante y humano. Las personas cuyas imágenes vemos en los periódicos no son banales, sólo son banales porque no son famosos". Esta banalidad no es meramente una variación de temas del Pop Art. El artista alemán mantiene siempre clara la división entre lo público y lo privado. Intenta extraer lo general de lo particular -y renuncia a limitar lo general a lo particular- mientras que Warhol negaba estas distinciones.

Para Ermin Buchloh, se trata de un recurso argumentativo mediante el que Richter ilustra el lado oscuro de la conciencia germano-occidental: la falta colectiva de afecto y la coraza psíquica con la que los alemanes de la postguerra se protegían contra el juicio de la historia (Buchloh, 1999, pp. 165-167). La exhibición de imágenes banales queda abruptamente interrumpida en el Atlas con la aparición de una serie de fotografías de víctimas del holocausto. En este momento Richter coloca al espectador frente a la visión duplicada de, por un lado, la muerte de la realidad en la fotografía y, por otro, la realidad de la muerte en la imagen mnemónica.

\section{Conclusión}

La obra de Richter, en todo su amplio repertorio formal, forjado a través de décadas de experimentación, nos transmite una cierta sensación de desconcierto ante la función del arte. Podríamos decir que esta incertidumbre sobre la tarea del arte y, en particular, de la pintura, constituye su dogma vanguardista (Rochlitz, 1999, p. 254). Podemos interpretar su obsesión por la imagen como un intento permanente de comprender lo que es, de una forma que refleja la incomprensibilidad de la obra de arte y el carácter inatacable de la experiencia estética. No obstante en su actividad podemos advertir también una cierta rebeldía que se muestra en su obstinación por pintar en contra de lo que parece ser el signo de los tiempos, o como actitud de lucha frente a las realidades que pretenden hacerse con el mundo a través de la imagen.

Tanto como fotógrafo como pintor, Richter "evita el tema" pero, al mismo tiempo, expresa la esperanza de "obtener un tema casi regalado, uno que yo no haya encontrado y que por eso habría de ser más universal, mejor, menos perecedero, más válido generalmente" (Zweite, 1999, p. 201). En esta indagación, el Atlas constituye la memoria visual, el palimpsesto del inconsciente (individual e histórico), que sustenta y tiende a dominar la obra pictórica (Chevier, 1999, p. 184). 
Cada panel es como un poema aislado de su recopilación y es sólo el conocimiento de las series, incluso de categorías enteras de obras, lo que permite acceder al sentido de exploración del artista, que no pretende extraer conclusiones, sino más bien exponer la realidad en su irreductibilidad y variabilidad continua.

\section{Referencias bibliográficas}

BUCHLOH, Benjamin (1999), "El Atlas de Gerhard Richter: el archivo anómico", en Fotografía y Pintura en la obra de Gerhard Richter, MACBA, Barcelona.

CHEVRIER, Jean François (1999), "Entre las bellas artes y los media (El ejemplo alemán: Gerhard Richter)”, en Fotografía y Pintura en la obra de Gerhard Richter, MACBA, Barcelona.

GIAVERI, Francesco (2011), "El Atlas de Gerhard Richter", en Anales de Historia del Arte, Universidad Complutense, Madrid.

KRACAUER, Siegfried (2008), La fotografía y otros ensayos, Gedisa, Barcelona.

ROCHLITZ, Rainer (!999), "El punto en que nos hallamos", en Fotografía y Pintura en la obra de Gerhard Richter, MACBA, Barcelona.

WARBURG, Aby (2010), Atlas Mnemosyne, Akal, Madrid.

ZWEITE, Armin (1999), "El Atlas de fotografías, collages y bocetos de Gerhard Richter”, en Fotografía y Pintura en la obra de Gerhard Richter, MACBA, Barcelona. 